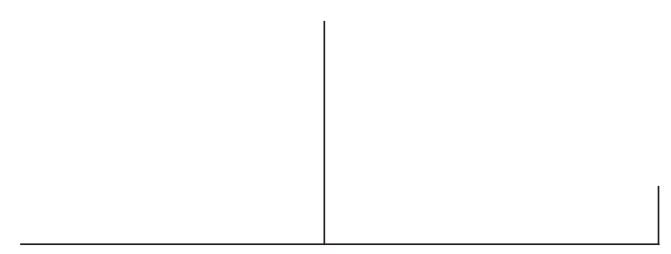

Rev. Latinoam. Psicop. Fund., II, 4, 123-142

\title{
A cordialidade como mal-estar ou a violência como o recalcado
}

\author{
Mériti de Souza
}

\begin{abstract}
Neste estudo problematizamos a constituição da subjetividade orientada pelo discurso que adota o mito do brasileiro cordial como modelo identificatório. Utilizando do referencial psicanalítico, analisamos discursos presentes na história nacional que abordam essa questão, interrogando sobre o recalque da violência e suas conseqüencias sobre a subjetividade. Avaliamos que o discurso da cordialidade funciona como forma de controle e de manutenção do status quo, ao gratificar e oferecer uma representação pretensamente valorizada do brasileiro. Ainda, esse discurso produz o recalque da violência e o seu retorno sob a forma de domínio, ou seja, de exercício do controle sobre o coro e o desejo do outro, manifesto nas práticas de dominação social e sexual. Os modelos identificatórios da cordialidade e do domínio, funcionam como extremos complementares, associados ao recalque da violência. Finalizando, perguntamos sobre as práticas psicoterápicas e psicanalíticas desenvolvidas no cenário nacional, a partir da inserção de psicoterapeutas e psicanalistas nesse contexto cultural.
\end{abstract}

Palavras-chave: Cordialidade, recalque, modelo identificatório, violência 


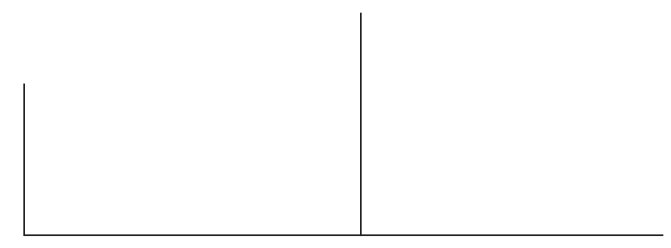

\section{Introdução}

Como sabemos, nenhum ato de colonização é pacífi$c o$, pois não respeita os valores culturais da terra que se propõe colonizar. A ordem da violência está presente no ato de colonizar, pois pressupõe a imposição de valores culturais sobre os já existentes na terra colonizada. Geralmente, dois argumentos sustentam a legitimidade do ato de colonização. O primeiro funda-se na suposição de que os valores culturais presentes na terra colonizada são de ordem inferior aos da sociedade colonizadora, e o segundo, decorrente do primeiro, desqualifica a cultura presente na nova terra e ao mesmo tempo valoriza os seus aspectos naturais.

Fundamental à tarefa da colonização da terra é o trabalho de colonização da alma. Aqui chegando nos idos de 1540, os padres, em sua maioria jesuítas, tiveram por mister conhecer os objetos de culto local, com o intuito de compreendê-los e destruí-los. A destruição implicava por vezes na adaptação desses ídolos à fé cristã e na sua desqualificação perante o "Deus verdadeiro e superior".

É recorrente encontrarmos, nos relatos de viagem de europeus que estiveram nas terras de Santa Cruz nos idos de 1500 e 1600, afirmações sobre a inexistência de qualquer culto ou resquício de fé entre os "gentios e pagãos". Sobre os habitantes da nova terra, Nicolas Barré, que acompanhou de 1556 a 1558 a expedição de Villegaignon, afirmou: "Tudo me leva a crer que esses nativos são o povo mais bárbaro e estranho que habita sobre a terra. Eles vivem sem conhecimento de nenhum Deus, sem inquietude de espírito, sem lei e sem nenhuma religião"1.

1. A esse respeito ver artigo de França, J.M.C. "A terra feliz sem lei nem rei”. In Folha de S. Paulo, caderno “Mais!”, 28/12/1997, p. 5-12. 


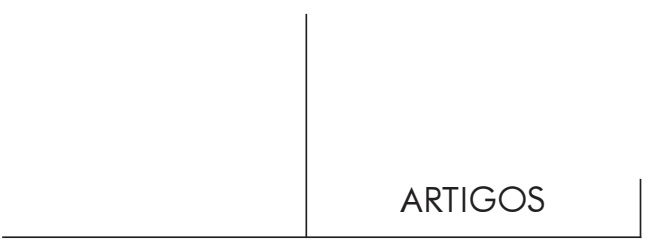

Crendo nesses relatos de viajantes e retomando nossos padres colonizadores, podemos suspeitar que a sua tarefa teria sido facilitada por essa inexistência de cultos, deuses e, conseqüentemente, de organização social e cultural. Entretanto, o próprio esforço e o relato dos prelados levam-nos a suspeitar de que a fé, a lei e o rei dos ameríndios não vestiam a mesma roupa dos europeus, dificultando seu reconhecimento pelos viajantes, mas não pelos olhos atentos dos que tinham por ofício enxergar além da roupa e do corpo. ${ }^{2}$

Assim, os olhos atentos dos padres enxergaram, mesmo que por dever de ofício e a contragosto, seu confrade, o Pajé, cumprindo a função de intermediar o contato entre a Divindade e o homem, e discerniram Jurupari, "senhor do culto mais vasto, comum a todas as tribos, filho e embaixador do Sol, nascido de mulher sem contato masculino, reformador, regenerador, de rito exigente, e de precauções misteriosas" ". O reconhecimento do outro é o primeiro passo na trajetória do contato com a diferença. O lidar com o diferente implica caminhos orientados pela constituição identitária dos envolvidos e, nesse ponto, o olhar etnocentrista prevaleceu no viajante e no jesuíta. O primeiro negando o estranho, o segundo reconhecendo-o e pregando a sua destruição, em nome do "Deus verdadeiro".

O culto de Jurupari, por estar disseminado e acompanhado de práticas litúrgicas, foi o escolhido pelos padres para ocupar o lugar do mal. O filho do Sol foi identificado com o Diabo, o Cão, Satanás. Esse procedimento desbancava a autoridade do pajé, intermediário do deus indígena, e desqualificava os valores e a cultura a ele associados. Em contrapartida, a produção de um Deus ameraba, associado ao cristianismo, era necessária. O escolhido foi Tupã, deus menor da teogonia ameríndia, incolor e inodoro, sem características definidas e nem cultos explicitados.

A doutrina de Jurupari previa ritos iniciatórios e festas, vedados às mulheres. Previa ainda normas, leis e valores. O homem deveria ser forte, fiel aos compromissos, resistente à dor e obediente. Jurupari é implacável, exige obediência às suas normas. Sua lei diz que todos devem casar cedo e ter uma só mulher. Puro, ele nunca permitiu que uma mulher tocasse seu corpo, aquelas que o fizeram foram transformadas em pedra. Definiu os ritos e festas do seu culto, para as quais

2. A literatura discute e aponta a presença da religiosidade e de cultos messiânicos e místicos entre as tribos indígenas nos séculos XV e XVI. A esse respeito consultar Vainfas, R. "Idolatrias luso-brasileiras: 'santidades' e milenarismos indígenas". In R. Vainfas (org.). América em tempo de conquista. Rio de Janeiro: Jorge Zahar, 1992; Queiroz, M.I.P. O messianisno no Brasil e no mundo. São Paulo: Alfa-Ômega, 1977.

3. Conforme L.C. Cascudo. Geografia dos mitos brasileiros. Brasília, José Olympio: 1976, pp. 41-42. 


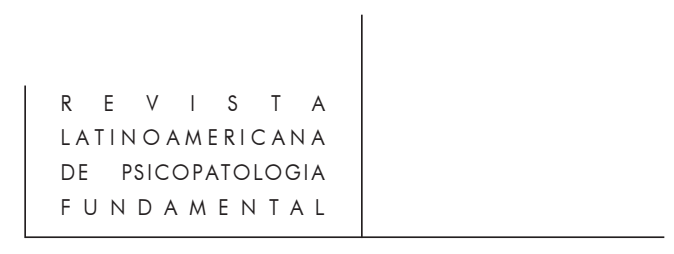

estabeleceu instrumentos a serem usados e segredos a serem conhecidos somente por homens. As mulheres que ouvissem ou vissem esses festejos, deveriam morrer. Por essa lei morreu Ceuci, a mãe de Jurupari.

Entendemos que Jurupari firma-se como um modelo de herói civilizador, que trouxe a "lei, a fé e a cultura" aos indígenas que habitavam o Brasil. Seu culto espalhava-se e era seguido pela maioria das tribos, apesar de encontrar-se modificado em cada região. Entretanto, podia ser reconhecido na maioria das tribos, por meio dos rituais complexos que o distinguiam. Danças, cantos, instrumentos-tabus como os maracás, a ausência de mulheres, ritos de iniciação e o pajé falando em nome de um deus, revelavam-no. Os nomes mudavam; porém, sua presença atravessou séculos e, ainda hoje, quando falam sobre seus deuses, é a ele que os índios se referem.

Legislador e reformador dos costumes, Jurupari definiu suas leis:

... pelas quais governam-se praticamente os nossos índios, tanto do Uaupés como do Içana e do Rio Negro: 1ํ) a mulher deverá conservar-se virgem até a puberdade; 2º) nunca deverá prostituir-se e há de ser sempre fiel ao seu marido; $3^{\circ}$ ) após o parto da mulher, deverá o marido abster-se de todo trabalho e de toda comida, pelo espaço de uma lua, a fim de que a força dessa lua passe para a criança; $4^{\circ}$ ) o chefe fraco será substituído pelo mais valente da tribo; 5으 o tuixaua poderá ter tantas mulheres quantas puder sustentar; 6을 a mulher estéril do tuixaua será abandonada e desprezada; 7으 o homem deverá sustentar-se com o trabalho de suas mãos; 8ํ) nunca a mulher poderá ver Jurupari a fim de castigá-la de alguns dos três defeitos nela dominantes: incontinência, curiosidade e facilidade de revelar segredos. (Cascudo, L.C., 1976, p. 76)

Em que pese nosso desagrado com as leis de Jurupari no trato com as mulheres, parece-nos inconteste a afirmação de leis e normas presentes na tradição cultural firmada e imposta por esse deus, ressaltando a sua predominância e disseminação entre os ameríndios. Ora, as implicações dessa tradição cultural para a organização social e para a vivência das leis pelos habitantes das terras de Santa Cruz são várias. Podemos destacar a existência de uma organização cultural na qual se sobressai a tentativa de estabelecer a filiação paterna e a identificação de pai com filho; a demarcação do lugar do tuixaua (chefe) e do pai na tribo e a garantia da sua linhagem; a garantia da subsistência da tribo e do lugar masculino; a demarcação do lugar feminino. Assim, desnecessário afirmar a existência da fé e da lei nessa cultura. Torna-se necessário, isto sim, discutir a afirmação de viajantes, e mesmo de alguns jesuítas, sobre a inexistência da fé e da lei entre os gentios.

O trabalho investido na escolha de Tupã como deus dos nativos, e de Jurupari como o demônio, chama nossa atenção, pois contrasta com a afirmação, presente nos relatos de viajantes e mesmo de jesuítas, da falta de lei e de cultura nas Terras de Santa Cruz. Os viajantes provavelmente não reconheceram a lei e a cultura nas 


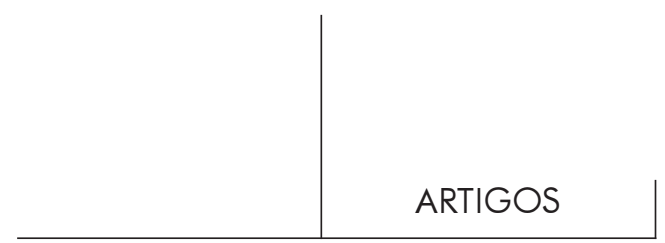

práticas do índio. Entretanto, alguns jesuítas as reconheceram; porém, adaptaramnas aos seus interesses e continuaram a afirmar, em suas cartas e pregações, a inexistência de um Deus-Pai nessas Terras. Daí a necessidade da construção de um, e da desqualificação de outro ${ }^{4}$.

No estudo sobre moralidade e práticas sexuais no Brasil colônia, Ronaldo Vainfas (1997) afirma que a maioria dos jesuítas enxergou nos corpos nus dos nativos, no direito do chefe e dos grandes guerreiros, no caso dos tupinambás, de ter várias mulheres, e na prática do casamento "in natural", apenas frenesi sexual, poligamia e incesto. A muito custo, Anchieta reconheceu essa prática entre os nativos. Nóbrega apontou, por parte dos aculturados portugueses e mesmo do clero, a poligamia e o "destempero sexual" para com os nativos, explicitando que a demanda por esses comportamentos encontrava-se naqueles que usavam roupas e eram guiados por uma cultura que tinha fé, lei e rei ${ }^{5}$.

Essa é uma questão muito discutida, que aponta para o etnocentrismo do europeu e para aspectos sociais e econômicos associados à dominação dos legítimos habitantes da terra. Representando-se os nativos como desqualificados e como bárbaros, tornavam-se tarefa santa e civilizatória a sua conquista e a sua adesão aos valores culturais dos colonizadores.

Entretanto, esse é apenas um dos lados da moeda. Acreditamos que a colonização no Brasil apresentou uma particularidade, pois não encontramos nela “apenas" a desvalorização da cultura da nova terra, mas também a negação dessa

4. Segundo Câmara Cascudo, "Não conheciam Deus. Era o depoimento unânime dos cronistas. Nem uma fé têm, nem adoram a Deus algum (frei Vicente do Salvador). Esta gentilidade nenhuma coisa adora, nem conhecem Deus (Padre Manuel da Nóbrega). Além de não revelarem conhecimento nenhum do verdadeiro Deus, não adoram nem confessam deuses falsos, celestiais ou terrestres (Jean de Léry). Nenhuma criatura adoram por Deus (Padre Anchieta). Este gentio não tem conhecimento algum de seu Criador, nem de coisa do céu (Padre Fernão Cardim). Não adoram coisa alguma (Pero de Magalhães Gandavo). Não tinham espécie alguma de religião (Cláudio d'Abbeville). Sem fé, sem lei, sem religião (André Thevet)." L.C. Cascudo. Geografia dos mitos brasileiros. Brasília: José Olympio, 1976, p. 54.

5. Vainfas (1997) ressalta a existência da lei indígena no tocante ao casamento e à prática sexual e que essa regulamentação não era reconhecida pela maioria dos colonizadores, pois chocava-se com os preceitos da Igreja, que pregava a monogamia e o impedimento da união carnal entre parentes até o quarto grau consanguíneo. O autor salienta que os praticantes e incentivadores das práticas que se chocavam com os preceitos culturais e religiosos dos portugueses eram os próprios colonizadores, que mantinham relacionamentos e tinham filhos com brancas e com índias. Casos famosos como o do português Caramuru (João Ramalho), que aderiu aos costumes nativos, casando-se com várias índias e com elas tendo muitos filhos, e mesmo o de membros do próprio clero, que se amancebavam com índias, foram denunciados por Nóbrega. R. Vainfas. "Moralidades brasílicas". In História da vida privada no Brasil - cotidiano e vida privada na América Portuguesa. São Paulo: Companhia das Letras, 1997. 


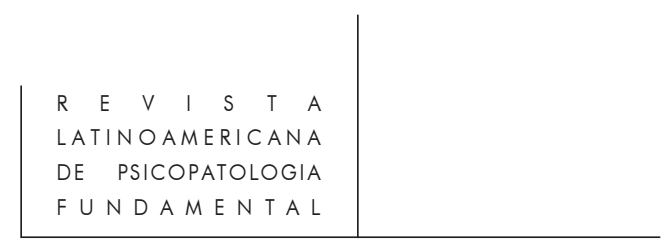

cultura por meio da sua "transformação" em elemento de ordem natural. Em outras palavras, a cultura indígena e o próprio índio foram representados como extensões da natureza, amalgamados e integrados à terra, perdendo a primeira a sua condição de produto da intervenção humana e o segundo o estatuto de sujeito.

Geralmente os movimentos de colonização utilizam-se da violência física, impondo-se pela força, e da violência simbólica, submetendo o colonizado por meio da desqualificação da sua cultura. $\mathrm{O}$ exercício da violência simbólica demanda, para sua operacionalização, a atribuição de um lugar ao outro, implicando o seu reconhecimento, mesmo que seja para submetê-lo. Entretanto, a prática da colonização no Brasil negou a cultura aqui presente e o seu produtor, afirmando a naturalização do índio e da sua cultura, e produzindo uma relação específica entre, de um lado, o colonizador e o outro colonizado e, de outro, o colonizador e o outro constitutivo da sua própria representação identitária.

\section{Construções identitárias, identidade e modernidade}

A crença na identidade como representante do eu e como marco de uma essência que caracteriza o sujeito revela-se produto da ordem liberal e moderna, definindo o sujeito da modernidade. Ginzburg (1992) aponta-nos o processo histórico que engendrou a criação e a utilização da noção de indivíduo e a constituição da idéia de identidade.

Para o autor, as sociedades sempre buscaram formas de distinguir os seus membros: os nomes, a descrição física e certas particularidades, como a assinatura, por exemplo. A noção de identidade e de individualidade veio cumprir uma função na nova ordem econômica capitalista, no sentido de fortalecer o poder estatal que estabelecia um controle qualitativo sobre as pessoas, localizando-as e identificandoas a partir da determinação de traços específicos e únicos que as caracterizariam. Tratava-se de uma forma de exercício de poder e de controle. ${ }^{6}$

6. Segundo Ginzburg (1992), somente nas últimas décadas do século XIX, principalmente na Europa, com o fortalecimento do conceito de propriedade e da legislação, que aumentara o controle sobre os delitos e as punições, surge a necessidade premente de identificação dos sujeitos, particularmente dos "criminosos e reincidentes", que atentavam contra as propriedades e as normas C. Ginzburg. Mitos, emblemas, sinais. São Paulo: Companhia das Letras, 1992. O conceito de identidade é considerado problemático pelo seu caráter de afirmação da essencialidade e de um modelo social. A construção da identidade revela-se como um auxiliar na manutenção da ordem vigente, pois, ao oferecer ao sujeito modelos identificatórios que lhe possibilitam essa construção, oferece-lhe a garantia da diferenciação - como se aquela identidade fosse a única e o caracterizasse. M. Selaibe. Identidade: formação e uso. São Paulo: PUC, 1987. (Dissertação). 


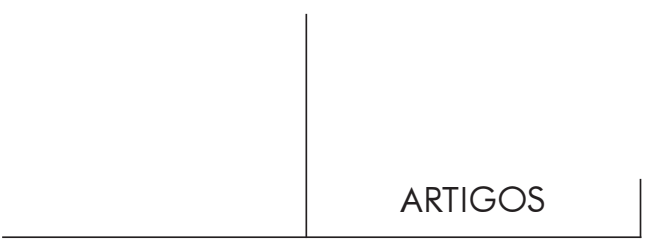

Como vemos, a constituição da subjetividade representada como identidade cumpre amplo papel, produzindo subjetividades pautadas pela adaptação, facilmente capturáveis pelo discurso tecnocrático da competência e embaladas pela crença racionalista de que controlam a si e ao mundo. Assim temos a crença, construída por uma subjetividade que se acredita senhora de si, dona dos seus atos, pensamentos e amores, palco do reinado da soberana consciência.

Como sabemos, a psicanálise questiona esse lugar de coincidência entre consciência e verdade, falando-nos da subjetividade cindida e de identificações (Freud, S., 1973a, 1973b, 1973c)7 . Acompanhando o referencial psicanalítico, supomos a representação da identidade como uma ficção, pois a constituição subjetiva acontece a partir de sucessivas identificações do sujeito com modelos identificatórios, oferecendo-lhe a ilusão de uma subjetividade linear e contínua.

Freire Costa (1986) releva o fato de que o sujeito se representa como constituído por uma constante temporal, percebendo seu psiquismo como uma identidade, tratando-se então esta de uma "ficção necessária à ação". Nicole Berry (1994) fala no mal-estar causado pela necessidade de constituição de uma representação que resolva o problema de ser do sujeito, apontando o sentimento de identidade como uma resposta a esse mal-estar ${ }^{8}$.

Acompanhando as ponderações dos autores, falaremos em construções identitárias, representações identitárias, ou mesmo sentimento de identidade, procurando, dessa forma, marcar o lugar de realidade psíquica que acompanha essa ficção construída pelo sujeito, ao mesmo tempo que procuramos preservar a crítica referente aos aspectos histórico e social, que produzem a organização psíquica baseada nessa crença.

A partir dessa perspectiva, entendemos que a construção identitária contempla uma série de assertivas e de interrogações. As primeiras referem-se à positividade

7. A discussão sobre a questão da identificação acompanha a obra freudiana. Podemos salientar os trabalhos Introducción al narcisismo, de 1914 e Duelo y melancolia, de 1915, nos quais o autor discute que a escolha objetal do sujeito - no caso, a narcísica - relaciona-se às suas identificações com objetos anteriores e que, na melancolia, o sujeito incorpora o objeto, existindo uma identificação entre sujeito e objeto perdido. Quando da elaboração da segunda teoria do aparelho psíquico, encontramos o trabalho Psicologia de las masas y analisis del 'yo', de 1921, onde o autor discute a existência de três modalidades de identificação, apontandonos que a identificação geralmente ocorre não com o objeto total, mas sim com algum traço seu. S. Freud. Introducción al narcisismo. Madrid: Biblioteca Nueva, 1973a; S. Freud. Duelo y melancolia. Madrid: Biblioteca Nueva, 1973b; S. Freud. Psicologia de las masas y analisis del 'yo'. Madrid, Biblioteca Nueva, 1973c.

8. Conforme o trabalho de J.F. Costa. Violência e psicanálise. Rio de Janeiro: Graal, 1986 e conforme a discussão realizada por N. Berry. O sentimento de identidade. São Paulo: Escuta, 1991. 
que caracterizaria uma pessoa e as segundas referem-se à negatividade dessa caracterização, ou seja, a definição de uma pessoa implica ela não ser uma outra pessoa. O outro aparece sempre como referência à construção identitária, pois a diferenciação em relação ao outro funciona como organizador e garantia para o sentimento de identidade. A diferenciação pressupõe uma indiferenciação inicial em relação a um outro.

Na colonização do Brasil, como pensar esse processo? A diferenciação em relação à mãe-natureza aconteceria a partir da entrada em cena de um pai-cultura. Entretanto, em nossa colonização, a especificidade da indiferenciação diz respeito à identificação com o modelo do pai-cultura e o modelo da mãe-terra, mediada pela negação produzida pelo colonizador do pai-cultura-nativo. Nesse processo, a indiferenciação é permeada pela memória oficial, construída a partir da narrativa sobre a existência de uma mãe natureza dadivosa e a inexistência de um pai cultura, o que demanda e justifica a intervenção do pai europeu para estabelecer a lei, a fé e a organização social, ou seja, para estabelecer a cultura.

Ora, qual cultura o pai europeu trouxe ao filho gentio? A resposta pode ser buscada no que foi desqualificado no modo de vida do nativo e no que foi preservado do modo de vida do europeu, ou seja, a que serviu o trabalho de aculturação do índio, e o que buscava o europeu preservar.

A negação da lei, da fé e da organização social presentes na cultura nativa no Brasil respondem à necessidade da manutenção da representação identitária do colonizador, sustentada por um ideal de eu marcado pela valorização da cultura, em detrimento das pulsões, e pela crença em um Pai que oferecia a vida eterna em troca do domínio do corpo. Assim, a transformação do Deus-Pai-Jurupari no demônio funcionou como reafirmação da legitimidade do Pai-Cultura-Europeu. Em outras palavras, foi necessário que os nativos reconhecessem que o Pai-Jurupari lhes oferecia uma representação identitária marcada por um aparente exercício sem culpa das pulsões, mas que, em "verdade", lhes cobrava a perda da alma.

Alma tão cara aos europeus, particularmente aos cristãos portugueses e espanhóis. Alma guardiã de um ideal de eu que garantia a manutenção de uma construção identitária sustentada na crença de filiação a um pai que resgataria seus filhos da morte, e dos sofrimentos terrenos, oferecendo-lhes a vida eterna e a felicidade. Entretanto, o preço cobrado pela vida eterna e pela manutenção de uma representação identitária marcada pela superação da morte e do sofrimento implicava a manutenção da fidelidade a um único Deus-Pai e a dominação do corpo, ou seja, da natureza humana com suas demandas pulsionais. Ora, aos olhos europeus, o gentio exultava nas suas práticas sexuais e violentas, vivendo seus impulsos sem culpa. Como suportar uma organização cultural na qual as pulsões podiam, aparentemente, ser exercidas sem sofrerem uma restrição tão violenta como na cultura européia e cristã? O colonizador não suportou confrontar-se com o expurgado 


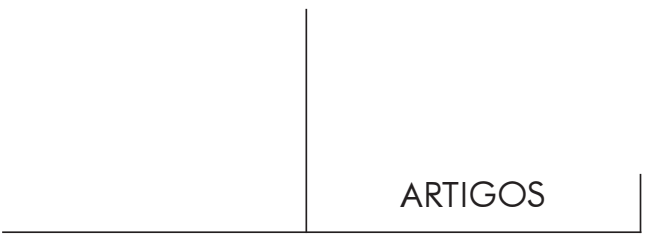

da sua representação identitária, reconhecendo nesse excluído sua demanda por uma outra relação com a cultura e com o Pai. Principalmente, ele não suportou a suposta felicidade reinante entre os gentios.

Freud, em um texto de 1930, fala-nos sobre a renúncia pulsional como necessária à organização cultural ocidental e cristã, e que essa renúncia implica a hostilidade dos sujeitos para com a cultura9 ${ }^{9}$ O autor localiza um dos motivos associados a essa hostilidade na dificuldade e mesmo intolerância do europeu para com a pretensa felicidade dos nativos encontrados nas terras "descobertas" durante as grandes navegações, pois

... ao estenderem-se as viagens de exploração se entabulou contato com raças e povos primitivos. Os europeus, observando superficialmente e interpretando de forma equívoca seus usos e costumes, imaginaram que esses povos levavam uma vida simples, modesta e feliz, que devia parecer inalcançavel aos exploradores de nível cultural mais elevado. (Freud, S., 1973, p. 3031) ${ }^{10}$

Acompanhando o autor, acreditamos que a reação do europeu, a possível felicidade dos nativos tupiniquins, e a sua impossibilidade em alcançá-la sem abandonar sua ordem cultural e principalmente a identificação operada com os ideais culturais por ela postos, redundou na desqualificação e negação da cultura indígena. Assim, a ordem cultural nativa, expressa na instituição da lei e da fé por Jurupari, foi desqualificada e negada, sendo reconhecida a ordem da natureza, dadivosa e pacífica. Esse ato inaugural assume repercussões na tradição cultural do país e na

9. Neste ponto é necessário comentar que não adotamos a concepção da violência como necessária à gênese da cultura e, por conseguinte, do psiquismo. Freire Costa (1986) critica a adoção por Freud, em alguns trabalhos, da crença de que a violência é inerente à constituição psíquica do sujeito e, portanto, das relações sociais. Para Freire Costa, no estudo de Freud Por que a Guerra?, encontramos a defesa da idéia de que existe um impulso agressivo "que pode coexistir perfeitamente com a possibilidade do homem empregar a violência" (p. 27). Amparado por essa idéia, Freire Costa defende que não existe um "impulso de violência", ou seja, a violência não se confunde com os impulsos agressivos humanos. Dessa forma, ele define violência como "o emprego desejado da agressividade, com fins destrutivos. Esse desejo poder ser voluntário, deliberado, racional e consciente, ou pode ser inconsciente, involuntário e irracional...[...]. Só existe violência no contexto da interação humana, onde a agressividade é instrumento de um desejo de destruição. Quando a ação agressiva é pura expressão do instinto ou quando não exprime um desejo de destruição, não é traduzida nem pelo sujeito, nem pelo observador como uma ação violenta" (p. 30). Finalizando, o autor pergunta por que a psicanálise, à revelia de seus referenciais teóricos e práticos, conclui que a violência produz cultura? Ele responde que é pela sobreposição equivocada entre poder e violência, que para ele não se sustenta. J. Freire Costa. "À guisa de introdução: Por que a violência? Por que a paz?”. In Violência e psicanálise. Rio de Janeiro: Graal, 1986.

10. S. Freud. El malestar en la cultura. Madrid: Biblioteca Nueva, 1973. 


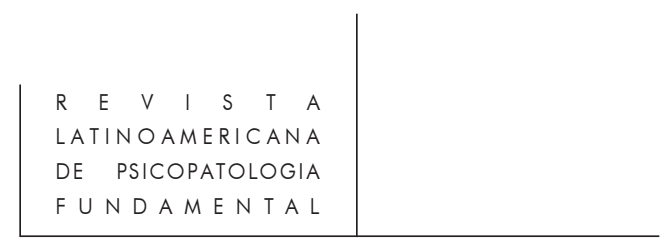

estruturação subjetiva dos descendentes dos gentios, já que a narrativa e a memória construída sobre a história brasileira apontam para a identificação do nativo com a natureza, construindo um lugar diferenciado para a entrada do sujeito na ordem cultural.

O sujeito se caracteriza pela sua historicidade, pela história demarcada por suas experiências imediatas e pela história inserida na tradição da sua cultura. Inferimos a constituição do sujeito ancorada em narrativas, aquelas construídas por ele sobre si mesmo e sobre o mundo que o cerca e aquelas a ele legadas pela tradição cultural da qual faz parte. A memória construída pelo sujeito acompanha essas narrativas, para ir constituindo sua representação identitária por meio da qual ele vai se reconhecer e reconhecer o outro. ${ }^{11}$

A narrativa construída sobre a história brasileira e a tradição cultural que a acompanha assumem lugar de destaque na constituição do sujeito. Assim, interessanos saber qual a ordem de mal-estar promovida pela inscrição do sujeito na ordem cultural brasileira? A angústia do mal-estar na civilização assume qual coloração no cenário nacional?

\section{A cordialidade como mal-estar}

As publicações de Raízes do Brasil, de Sérgio B. de Hollanda, em 1936, e de Casa-grande e senzala, de Gilberto Freyre, em 1933, estabelecem marcos no estudo sobre a formação da sociedade nacional. A primeira obra analisa a cultura brasileira a partir da tradição ibérica e da escravidão, pontuando a constituição de uma ordem marcada pelo ruralismo como prática econômica e na qual predominam as relações pessoais. A segunda obra critica os discursos higienistas predominantes na época, baseados na idéia da inferioridade da raça negra e discute a miscigenação como um fator positivo na organização das estruturas sociais e culturais nacionais. ${ }^{12}$

Essas duas obras, capitais ao conhecimento da organização da cultura brasileira, ajudaram a explicitar e disseminar a interpretação, presente no imaginário nacional, do brasileiro como cordial, avesso à violência, capaz de aceitar o convívio com outras raças e outros povos, aceitando o diferente com facilidade. Essas interpretações, predominantes na tradição cultural nacional, produzem seus frutos, incluindo a representação do brasileiro como cordial e avesso à discriminação. ${ }^{13}$

11. A esse respeito ver a discussão de Birman, J. "Um futuro para a psicanálise?”. In Estilo e modernidade em psicanálise. São Paulo: Editora 34, 1997.

12. S.B. Hollanda. Raízes do Brasil. Rio de Janeiro: José Olympio, 1994. G. Freyre. Casa-grande e senzala. Rio de Janeiro/Brasília: INL-MEC, 1980.

13. Salientamos que essas obras não "afirmaram e não criaram" necessariamente essas interpretações. Esses trabalhos traduzem aspectos presentes na tradição cultural brasileira. Entretanto, 


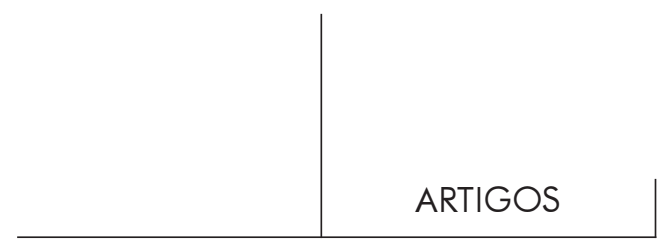

Assim, é muito freqüente na história nacional, quando da organização pela população de ações reivindicatórias violentas, imediatamente erguer-se uma voz a denunciar a intromissão de elementos perigosos ou subversivos. A justificativa utilizada é a de que o pacífico brasileiro jamais se prestaria a atitudes de violência ou contestação. Trata-se, é claro, argumenta a mesma voz, de agitação provocada por elementos estranhos, sejam eles quais forem. Assim, num discurso subjacente, se transmite a mensagem que reforça a imagem do brasileiro, cobrando-lhe o retorno à sua cordialidade, ou seja, às suas origens e existência naturais ${ }^{14}$.

Nossa atenção recai sobre esses "elementos estranhos". Por um lado, podese tratar de atributos entendidos como não pertencentes ao brasileiro ou, por outro, de pessoas que não detêm essa nacionalidade. De qualquer forma, o estranho diz respeito a características que não compõem a "suposta identidade" do brasileiro, ou então, diz respeito a estrangeiros reunindo em comum o fato de apresentarem elementos estranhos aos que constituem e caracterizam o brasileiro.

Como sabemos, o excluído tem força fundante na construção das identificações, pois, apesar de apartado da consciência - da memória -, ele atua sobre a própria constituição da memória e da narrativa. A narrativa elaborada pelo sujeito sobre ele mesmo e sobre as situações e fatos que o circundam sofre a força do excluído, ainda que essa força se manifeste sob a forma de negação. Como vemos, o explícito também diz do excluído, só assumindo esse lugar por força da sua relação com este último.

O medo do estranho, do diferente, pode emergir tanto da idéia de perda de privilégios e de estabilidade econômica e social, como da perda da estabilidade produzida pela ilusão identitária, conseguida pela manutenção de representações cristalizadas sobre si mesmo, sobre o outro e o mundo. Assim, a representação que aponta o Brasil e os brasileiros como uma nação e um povo desprovidos de preconceitos e aptos a lidarem muito bem com as diferenças, sejam elas étnicas, econômicas ou sociais, na verdade diz muito mais acerca de uma estratégia construída com o intuito de incutir nas pessoas a representação de cordiais, avessas

a força da assimilação e apropriação popular produziu esses estereótipos sobre a cultura e sobre o homem brasileiro.

14. Tratando do natural e da origem no Brasil, esses requisitos geralmente são associados à "docilidade, pureza e ingenuidade" do índio, que recebeu os portugueses de braços abertos. Podemos notar que episódios envolvendo "aspectos violentos", como a deglutição do Bispo Sardinha pelos índios Aimorés, foram praticamente banidos da memória nacional. Segundo DaMatta, a benevolência da natureza, que brindou o país com a mais bela geografia, também é associada à tranqüilidade e à mansidão da nossa gente. Cf. R. DaMatta. Conta de mentiroso-sete ensaios de antropologia nacional. Rio de Janeiro: Rocco, 1993. 


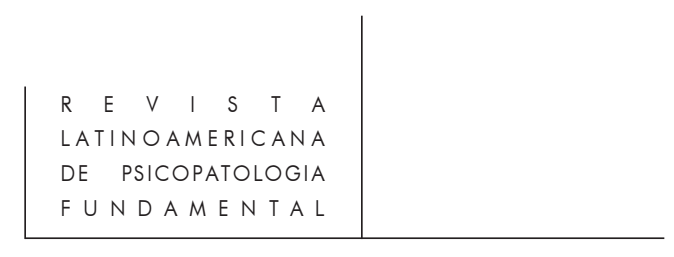

à violência. A relação se estabelece, nesse caso, a partir do seguinte raciocínio: se o brasileiro aceita muito bem as diferenças, sendo esse um aspecto valorizado, ele também aceita a diferença social.

Esse contexto possibilita a produção no país de subjetividades orientadas pelo "dever ser alegre, cordial", por nós denominado "devir carnavalizado". Essas subjetividades seriam pautadas pelo princípio da cordialidade, constituídas pela crença que valoriza a exclusão dos redutos do eu da violência e valoriza a necessidade de o eu realizar o controle de impulsos violentos. O discurso produtor dessa crença pretende a exclusão da violência na representação identitária dos brasileiros e adota a idéia de que ela é nociva e desnecessária ao próprio movimento da constituição subjetiva.

Entretanto, acreditamos que a incorporação de uma memória e de uma narrativa construída a partir da história oficial dá-se pela interpretação seletiva e parcial. O esquecimento é seletivo, nunca aleatório, e revela sua eficácia porque, além dos interesses classistas envolvidos, também atende ao interesse dos brasileiros em manterem afastadas situações e fatos frustrantes. Porém, o mais importante, nesse processo, é que a incorporação da memória oficial sobre a nação produz subjetividades que se reconhecem nesse "passado" e nas representações por ele construídas.

A visão oficial também representa nossa história, pois ela se encontra disseminada, com boa parte das pessoas reproduzindo-a e acreditando nela. Ainda mais, ela representa justamente o jogo de forças em nossas relações sociais. Esse jogo de forças exclui os fatos e as pessoas por meio dos quais os brasileiros surgem como contestadores e violentos, estabelecendo a imagem de cordialidade e matreirice. Essa exclusão interessa para alguns, pois ajuda a manter uma construção identitária que justifica a posição neutra, eximindo o sujeito de maiores comprometimentos com a intervenção no real. Ao mesmo tempo, interessa para outros, já que possibilita a manutenção do status quo, ao disseminar representações que reforçam a inércia social do brasileiro, retratando-o como cordial e pacato.

Visualizamos as estacas que sustentam a idéia da cordialidade nacional e percebemos que elas permanecem em pé, em decorrência do amparo oferecido à manutenção de uma construção identitária valorizada, ou seja, a cordialidade funciona como modelo identificatório, produzindo uma representação identitária valorizada e assumida pela maioria das pessoas. E mais: ela contrapõe-se ao reconhecimento da extrema desigualdade social observada no país, servindo como "justificativa" para a convivência e a aceitação dessa realidade. Em outras palavras, supomos que a presença de valores e aspectos a serem valorizados faz-se urgente para a manutenção da frágil auto-estima dos brasileiros. Assim, o processo de idealização da cordialidade entra em cena, negando outros aspectos, como a organização social, que poderiam conturbar ou desalojar a consistência do valorizado. 


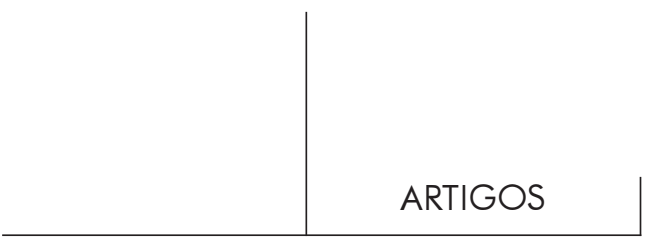

Em suma, supomos o lugar de recalque ocupado pela violência na memória nacional, redundando na produção de modelos identificatórios associados à cordialidade e na representação identitária do brasileiro como pacífico e avesso a ações discriminatórias. Entretanto, as práticas sociais presentes em nossa história apontam para inúmeras manifestações e experiências que atestam a presença e o uso da violência. Dessa forma, apesar de não negarmos a incorporação da representação da cordialidade por uma parcela da população, interessa-nos ressaltar que a manifestação da violência ocorreu e ocorre à revelia dessa injunção.

Assim, reconhecendo a atuação da violência na história nacional e na vida da maioria das pessoas, teremos de assumir o fracasso da injunção do "devir carnavalizado"? Não necessariamente, pois supomos a violência assumindo diferentes caminhos, sendo a cordialidade um dos possíveis. Nossa pergunta recai sobre os outros caminhos seguidos pela violência em nossa história. A quais representações as pulsões agressivas se ligaram ${ }^{15}$ ? Nossa suposição é a de que a representação do brasileiro como cordial responde por um desses caminhos. Além disso, acreditamos que uma outra trajetória indica o exercício da dominação como manifestação da violência e do impulso agressivo.

15. Utilizamos o conceito de pulsão de agressão, pois Freud o emprega de forma cambiável com outras denominações. A partir da publicação, em 1920, de "Além do princípio do prazer", consolida-se a definição da pulsão de morte, que vai encampar as noções de pulsão de destruição, de agressão, destrutivas etc. $\mathrm{O}$ autor afirma que "a tendência agressiva é uma disposição instintiva inata e autônoma do ser humano." S. Freud. El malestar en la cultura. Madrid: Biblioteca Nueva, 1973, p. 3052. Em um texto de 1932, o autor afirma a existência de duas classes de pulsões essencialmente diferentes, as pulsões sexuais e as pulsões de agressão, cujo fim é a destruição. S. Freud. Nuevas lecciones introductorias al psicoanalisis. Madrid: Biblioteca Nueva, 1973, p. 3159. Ainda em outra obra de 1932, afirma-se a pulsão de agressão como originando-se da pulsão de morte "a pulsão de morte se torna pulsão de destruição quando, com a ajuda de órgãos especiais, é dirigido para fora, para os objetos. O ser vivente proteje em certa maneira sua própria vida destruindo a vida alheia. Porém uma parte da pulsão de morte se mantém ativa no interior do ser; temos tratado de explicar grande número de fenômenos normais e patológicos mediante esta interiorização da pulsão de destruição". S. Freud. El porqué de la guerra. Madrid: Biblioteca Nueva, 1973, p. 3212 e 3213. Como vemos, trata-se de uma discussão complexa, pois, inicialmente, o autor a entendia como uma ação voltada para o exterior que se volta para o interior do próprio sujeito a partir das relações que este estabelece com o objeto e consigo mesmo. Posteriormente, depois de 1920, ela é entendida a partir das relações entre diferentes instâncias, ou seja, do conflito entre supereu e eu. De qualquer forma, interessa-nos que o autor estabelece uma teoria da agressividade, amparando nossa discussão. 


\section{A dominação como forma de manter a representação identitária}

Constatamos que a dominação é uma marca recorrente em nossa história. Inúmeros autores nos informam que o exercício dessa prática marcou as relações no Brasil Colônia, atravessando a República e mantendo-se na atualidade. As relações de domínio, quer sobre o índio, o negro ou sobre o trabalhador livre, quer sobre o par amoroso, constituem-se em experiências marcantes em nossa vida cultural e social explicitando que, nas relações sociais ou nas relações sexuais, encontramos o desejo de dominação do corpo do outro ${ }^{16}$.

Segundo Ronaldo Vainfas (1997), a rudeza e a falta de honra, atribuídas às índias e negras pelos portugueses, serviram de argumento para a sedução e a sujeição a que elas foram submetidas. O autor afirma que o "argumento" sobre a nudez dos índios, que revelaria sua luxúria e incitaria os colonizadores, não se sustenta, pois, na Europa quinhentista, a nudez era comum em algumas situações, como na prática de banhos coletivos. Além disso, o domínio do senhor sobre o escravo, apesar da exuberância dos signos da posse e do lugar ocupado por cada personagem na relação, necessitou cada vez mais de um número infindável de signos que reafirmassem esses lugares. Assim, Alencastro (1997) nos relata que, em 1858, apareceu na Praça do Comércio um branco de olhos azuis e cabelos louros, solicitando dinheiro para comprar sua alforria. Os presentes se escandalizaram e não acreditaram na existência de um escravo branco. Depois de ele confirmar sua condição, imediatamente foi levantada a quantia de 1600 contos de réis para garantir a liberdade do cativo, tamanho o mal-estar que essa situação causou nos presentes ${ }^{17}$.

16. A esse respeito encontramos a discussão de Calligaris (1993), na qual o autor aponta a presença, na vida social e sexual dos brasileiros, do domínio sobre o corpo do outro. C. Calligaris. "Por que rimar amor e dor". In Revista da Folha. São Paulo, ano 2, no 59, junho de 1993.

17. Um desses signos diz respeito ao impedimento feito ao escravo de usar calçados, pois, na medida em que a escravidão se ampliava, passou a incorporar brancos e praticantes de artes e ofícios, englobando no estatuto da escravidão pessoas portadoras de sinais que anteriormente serviam para demarcar a separação entre senhores e cativos. Ainda, os argumentos brandidos pelos colonizadores sobre a lascívia dos corpos nus dos nativos e a "facilidade e falta de honra das mulheres negras e índias", que provocariam a sua rendição ante os apelos eróticos do outro, não resistem ao cotejo com a prática social. Reafirma esse argumento a discussão de Mary Del Priore (1997), apud Alencastro (1997), ao comentar que a erotização das nádegas e das ancas, presente na cultura nacional, acompanha o que se escondeu nos corpos das negras escravas, e não o que se expunha. Ou seja, por séculos as negras andaram com os seios descobertos nas ruas e nas casas, cobrindo o corpo da cintura para baixo. Segundo a autora, não são os seios, que ficaram expostos cotidianamente por séculos, que se constituíram em objeto de desejo nacional, mas sim o que ficou encoberto pelas saias e se oferecia 


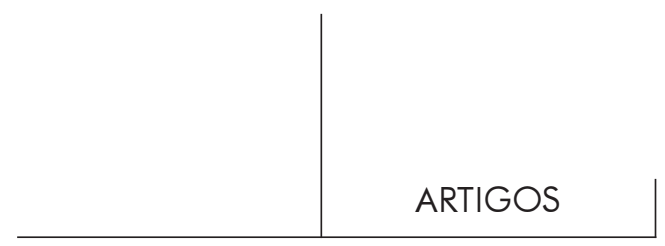

Nas situações anteriormente apontadas, a necessidade de manutenção da representação identitária mobiliza o restabelecimento do lugar ocupado pelos sujeitos em relações marcadas pelo exercício da dominação. Assim, a atração pelo nativo, justificada pelo colono a partir da exibição do seu corpo, revelaria não tanto o estranhamento do português ante o corpo nu, mas a dificuldade em manter a demarcação das diferenças esmaecidas no contato sexual. Assim, a necessidade de mediar esse contato por meio do domínio desse corpo. Ainda, a intolerância ao se encontrar alguém detentor de uma característica - cor da pele -, que supostamente garantiria um lugar na relação senhor e escravo, desestabilizou a frágil construção identitária demarcada por esses lugares, obrigando os presentes a repararem rapidamente essa situação. Essas situações explicitam tanto a dificuldade do europeu em sustentar a sua representação como aculturado, cristão, e superior, ante o desejo despertado por uma índia ou uma negra, quanto a dificuldade, vivenciada séculos depois, por brasileiros em manterem sua representação como superior e livre, mediante um branco na condição de escravo. No primeiro caso, a garantia da ficção identitária foi oferecida pelo argumento de que o desejo não emanava do europeu, mas sim era "produzido por uma fonte externa", pela lascívia do outro. No segundo caso, a garantia era oferecida pela justificativa de que a escravização era exercida sobre um inferior, marcando-se assim a diferença em relação ao senhor branco.

Como vemos, a crença de que se sucumbia à prática da dominação, nas relações sexuais e sociais, diante de um outro "coisificado", buscava garantir o estranhamento na relação de domínio, sustentando-a. A coisificação do escravo e do nativo (índio e negro), e a instrumentalização do seu corpo e do seu desejo, explicitavam o domínio como um exercício extremo de manutenção da identidade. Ou seja, as relações entre construção identitária e dominação dizem respeito à manutenção da identidade, já que o exercício da instrumentalização do outro pode funcionar como recurso extremo para marcar a diferença entre dominador e dominado $^{18}$.

requebrando e remexendo nos lundus e nos batuques. L.F. Alencastro. "Vida privada e ordem privada no império". In História da vida privada no Brasil: Império - a corte e a modernidade nacional. São Paulo: Companhia das Letras, 1997.

18. Seguindo esse raciocínio, teríamos a ação da dominação como forma de controlar o medo gerado pelo estranho, pelo diferente, representado pelo negro. Esse estranho diz respeito, entre outros aspectos, à prática da violência pelo negro em relação ao branco, que desestabiliza a relação de dominação e os lugares por ela instituídos. A libertação dos escravos no século XIX é vista como marco da entrada do país na ordem do progresso e da civilidade. Entretanto, a libertação dos escravos também é analisada como uma reação do branco à violência do escravo para com seus senhores. Alencastro (1997) relata a história, publicada nos jornais da corte, de uma escrava cozinheira que, após envenenar seis pessoas de uma mesma família, 


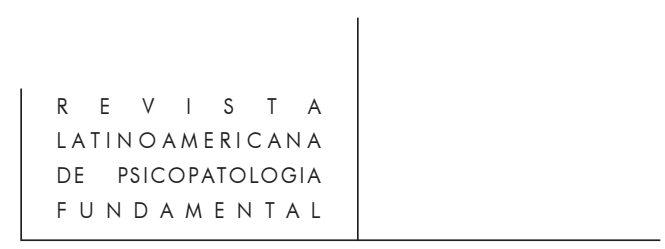

Outrossim, a cordialidade, ao forjar uma representação identitária que se esquiva de lidar com a violência, funciona procurando anestesiar o sofrimento psíquico gerado pelo mal-estar causado pelo confronto do sujeito com esse conteúdo. Ou seja, o recalque da violência na memória nacional procura dar conta do mal-estar causado pela exacerbação de práticas violentas, funcionando a cordialidade como contraponto dessa exacerbação.

A constituição identitária associada a uma ordem cultural, que estabelece no discurso fundador a "coisificação" do seu sujeito, pela sua naturalização, conforme discutimos anteriormente, produz seus frutos. Por um lado, a dominação como forma de marcar identidade, dermarcando um sujeito desejante que necessita controlar seu objeto, possuí-lo, para preservar seu lugar diferenciado. Por outro, a cordialidade como forma de sustentar um lugar identitário valorizado. Construções complementares: o cordial, que "reconhece e aceita" o estranho e o dominador, que não reconhece e coisifica o outro. Duas refrações de um mesmo caleidoscópio, refletindo a luz da violência recalcada.

\section{Nós, profissionais, marcados pelo recalque da violência ${ }^{19}$}

Constituímos uma cultura e nos constituímos em uma cultura que produz a cordialidade e a dominação como expressões do recalque da violência. A entrada na ordem cultural orientada por esses caminhos seguidos pela violência marca a nossa constituição identitária. Assim, em nossa vida profissional (e, claro, na nossa vida cotidiana) elaboramos representações sobre o outro e sobre seu sofrimento, marcadas por essa tradição cultural.

Em outras palavras, pressupondo uma cultura produtora de modelos identificatórios marcados pelo recalque da violência, e a dominação e a cordialidade como produtos desse recalque, quais as repercussões desse contexto em nossa subjetividade e, conseqüentemente, em nossa prática profissional? A institucionalização de

foi vendida e realizou dois novos envenenamentos na nova família, o que não impediu que essa nova família alugasse a escrava a terceiros, continuando a envenenar seus quitutes e seus comensais. L.F. Alencastro. "Vida privada e ordem privada no império". In História da vida privada no Brasil: Império. São Paulo: Companhia das Letras, 1997. A questão do medo do negro pelo branco é também discutida por C.M.M. Azevedo. Onda negra, medo branco: o negro no imaginário das elites - século XIX. Rio de Janeiro: Paz e Terra, 1987.

19. A intenção, ao escrever "nós-profissionais", era a de me referir a nós como praticantes de uma profissão; entretanto, posteriormente percebi que esse "nós" poderia referir-se também ao intrincado, ao nó (ou aos nós) do difícil exercício da profissão voltada para o trabalho psicológico. 


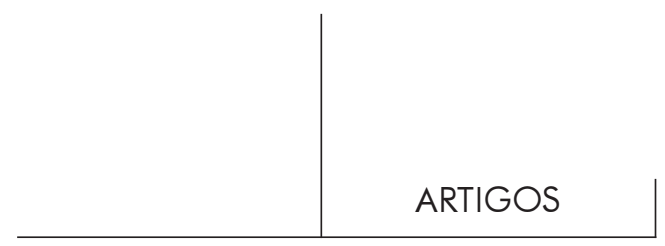

práticas marcadas pela hierarquização e pela adoção acrítica de teorias orientadas por modelos definidos a priori, a necessidade de resguardar a universalidade da constituição psíquica, sacramentando um modelo atemporal de sujeito, poderiam definir um lugar de domínio sobre o outro. Lugar simbólico de usufruto do sofrimento e do corpo do outro que, à mercê do discurso psicoterápico ou psicanalítico, tem seu corpo e seu desejo submetidos à doutrina do profissional ${ }^{20}$.

O domínio sobre o saber que o outro produz sobre si mesmo e sobre o mundo é apropriado, ou pretensamente apropriado, por teorias e por profissionais que se arvoram em conhecedores a priori do funcionamento psíquico do outro, supondo deter as respostas às suas angústias. O saber construído sobre a universalidade do psiquismo e sobre uma teoria e uma técnica que conhecem e dominam a estrutura psíquica funciona como tentativa de aplacar a angústia gerada pelo não saber sobre a singularidade do sofrimento de cada um (e possivelmente sobre o próprio sofrimento).

Além disso, o saber apriorístico responde ao medo de se ver dissipada a identidade do profissional, que supostamente garante o saber sobre o outro e sobre si mesmo. O deixar-se afetar pelo outro, produzindo conjuntamente conhecimento sobre o sofrimento, implica a tolerância para suportar o desconhecimento sobre o outro à nossa frente e sobre o outro que nos habita.

Por seu turno, a extrema cordialidade pode ser encontrada em práticas que oferecem a visão do sofrimento como partilhada e anulada no convidativo carnaval de hapennings realizados em finais de semana em paradisíacas fazendas e hotéis. Mesmo no discreto consultório, a prática do relacionamento informal e acolhedor substitui o trabalho da escuta clínica pelo da conversa superficial. Parodiando Hannah Arendt ${ }^{21}$, quando esta nos fala da banalização do mal, a banalização do sofrimento pode configurar-se como um ato de extrema violência. Assim, práticas que se deixam seduzir pela idéia da "cura fácil" oferecem-nos a visão do sofrimento esvaindo-se do corpo e da alma após a receptiva e calorosa acolhida por parte do profissional.

A necessidade de categorizar o sofrimento à nossa frente (e aquele que nos habita) e a necessidade de banalizar esse sofrimento não seriam sintomas da nossa

20. Os debates sobre a questão da psicanálise inserida em uma tradição cultural, geralmente, vêm acompanhados por discursos que reafirmam o sujeito universal e a filiação dos psicanalistas à tradição européia, como que a demonstrar a garantia da identificação do sujeito tupiniquim com seus irmãos do norte. Exemplificamos com o debate sobre a identidade da psicanálise no Brasil, marcado pelo acirramento dessa posição ante a universalidade do psiquismo e conseqüentemente de uma pretensa identidade entre os psicanalistas europeus e brasileiros. Revista Brasileira de Psicanálise. Psicanálise Brasileira? Vol. XXV, no 01, 1991, pp. 109-146.

21. H. Arendt. "Da violência". In Crises da república. São Paulo: Perspectiva, 1973; H. Arendt. Entre o passado e o futuro. São Paulo: Perspectiva, 1992. 


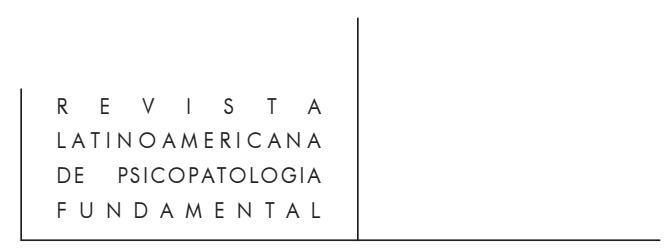

entrada em uma ordem cultural marcada pela cordialidade e pelo domínio? A dificuldade de alguns profissionais em reconhecerem e lidarem com a transferência e com a contratransferência, bem como a sua insistência em manter a concepção de subjetividades universais e técnicas e teorias estandardizadas, não seriam outros exemplos da mesma situação?

A própria dificuldade da crítica ao instrumento de trabalho pode acompanhar essas situações. A adesão irrestrita a alguma teoria ou escola produz uma visão de mundo a partir da eleição de um conhecimento capaz de suturar a marca da castração, e aplacar a angústia produzida por essa condição. Essa maneira de lidar com o saber psicanalítico e psicoterápico implica a produção da crença de um solo comum, que delimitaria e caracterizaria as diversas correntes e as práticas analíticas $^{22}$.

A psicopatologia fundamental pressupõe o trabalho com a transferência e a contratransferência, bem como o trabalho clínico ancorado na produção de um saber conjunto sobre o sofrimento psíquico, produzido pelo par terapêutico ${ }^{23}$. Essa prática demanda o reconhecimento de um sujeito singular e das suas relações com a tradição cultural na qual encontra-se inscrito. Quais possibilidades se abrem para essa área de conhecimento, orientada pela posição ocupada pelo profissional e pelo saber, ante a ordem cultural nacional e seus modelos identificatórios? Como pensar a disseminação e a implantação da psicopatologia fundamental?

Salientamos que nosso intuito não é ser contra ou a favor dessa ou daquela prática psicoterápica ou psicanalítica mas, antes, discutir as demandas por essas práticas e suas relações com a construção identitária e com os modelos identificatórios presentes em nossa cultura. Interessa-nos perguntar pelo trabalho com a transferência e com a contratransferência que demanda a construção de um saber sobre o sofrimento psíquico, implicando a tolerância do profissional para com seu não-saber. Nessa posição, a construção de novos sentidos para as experiências mobilizam o sentimento de identidade, gerando medo nos envolvidos no trabalho terapêutico mas, ao mesmo tempo, possibilitando-lhes inscreverem-se em novas ordens simbólicas, produzindo novas narrativas sobre si mesmo e sobre o mundo.

Não pretendemos responder a essas questões e nem acreditamos que exista uma resposta, no sentido de estabelecer uma solução. Interessa-nos reconhecer e

22. S.A. Figueira. Freud e a difusão da psicanálise. Porto Alegre: Artes Médicas, 1994.

23. Encontramos a discussão sobre a transferência e a contratransferência no trabalho clínico em P. Fédida. Clínica psicanalítica. São Paulo: Escuta, 1988. Sobre a produção conjunta, pelo par analítico, do saber acerca do sofrimento, localizamos M.T. Berlinck. "O que é Psicopatologia Fundamental”. In Revista Latinoamericana de Psicopatologia Fundamental. São Paulo, vol. 1, no 1, março de 1998. 


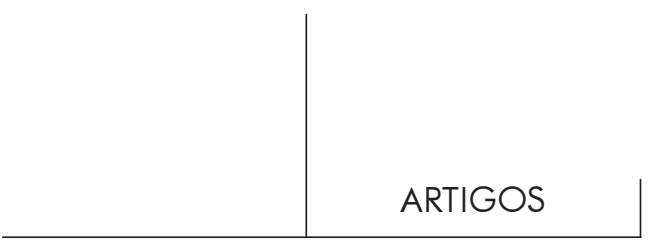

problematizar as diferentes tradições culturais e, consequientemente, as tradições psicoterápicas e psicanalíticas. Interessa-nos ainda perguntar sobre as relações entre a constituição identitária do sujeito e sua prática profissional, pois o trabalho terapêutico demanda o contato com o nosso sofrimento para podermos reverberar e escutar o sofrimento do outro.

\section{Resumos}

En este análisis discutiremos la constitución de la subjetividad orientada por lo discurso que adopta el mito del brasileño cordial como modelo de identificación. Utilizando como referencia la psicoanálisis, analizamos discursos presentes en la historia nacional que abordan esa cuestión, interrogando sobre la represión de la violencia en sus consecuencias sobre la subjetividad. Evaluamos que el discurso de la cordialidad funciona como forma de control y de mantenimiento del status quo, cuando gratifica y ofrece una representación pretensamente valorizada del brasileño. Los modelos identificatorios de la cordialidad y del dominio funcionan como extremos complementares, asociados a la represión de la violencia. Finalizando, preguntamos sobre las prácticas psicoterapicas y psicoanalíticas desarolladas en el escenario nacional desde la inserción de psicoterapeutas y psicoanalistas en ese contexto cultural.

Palabras llave: Cordialidad, represión, modelos identificatorios, violencia

On étude ici la constitution de la subjetivité orientée pour le discours qui adopte le mythe du brésilien cordial comme modèle de identification. En utilisant de la psychanalyse, on analyse les discours presents dans l'histoire national que abordent cette question, en interrogeant sur le refoulement de la violence et las conséquences sur la subjetivité. On évalue que le discours de la cordialité functionne comme forme de contrôle et de maintenance $d u$ status quo, quand gratifie e offre une représentation valorisée du brésilien. Et cet discours produit le refoulement de la violence et son retour sous la forme de de domaine. Les modèles identificatoires de la cordialité et de domaine functionnent comme extrêmes complementaires, associée au refoulement de la violence. Pour finaliser, on demande sur les pratiques psychotherapiques et psychanalytiques développées dans le décor national, à partir de la insertion de thérapeutes et psychanalistes dans ce contexte culturel.

Mots cles: Cordialité, refoulement, functionnent complementaires, violence

This essay deals with the question about the constitution of the subjectivity oriented by the speech that adopts the myth of the Brazilian people's cordiality as a model of identification. Using a psychoanalytical background, we take from Brazilian history some speeches (related to this question) which are analyzed by interrogating ourselves about the violence repression and its consequences upon the subjectivity. As far as we are concerned, we presume that this speech of cordiality works as a controlling and 


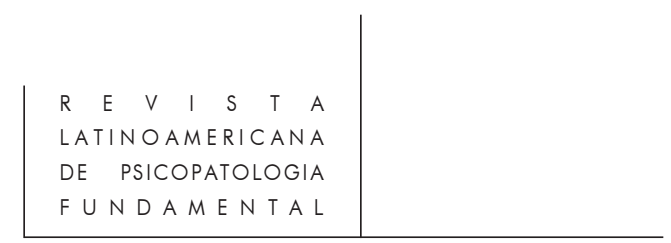

sustaining frame of status quo, since it gratifies and offers a pretense representation of the Brazilian people. Besides, this speech triggers the violence repression and its return under the guise of domination, i.e., the exercise of the control over the body and the Other's desire that manifests itself in the pratices of social and sexual domination. These cordiality models of identification and domination act as complementary poles associated with the violence repression. We finally think over the psychoanalytical and psychotherapeutics practices developed out of the national scene since the entering of psychoanalysts and psychotherapists in this cultural context.

Key words: Cordiality, repression, model of identification, violence 